\title{
The behaviour of migratory eels, Anguilla rostrata, in response to current, salinity and lunar period"
}

\author{
J. H. W. HAIN \\ Graduate School of Oceanography University of Rhode Island; \\ Kingston, Rbode Island, USA
}

\begin{abstract}
KURZFASSUNG: Das Verhalten von Wanderaalen, Anguilla rostrata, gegenüber Strömung, Salzgehalt und Lunarperiode. Das Verhalten von wandernden Blankaalen (Anguilla rostrata) wurde in einem Dreikammersystem untersucht und mit demjenigen von Gelbaalen verglichen. Blankaale, die während ihrer seewärts gerichteten Flußwanderung gefangen worden waren, zeigten bei Untersuchungen im Süßwasser eine negative Rheotaxis, wurden jedoch bei Einleitung von Seewasser positiv rheotaktisch. Die Reaktionen von Aalen, deren Geruchsepithel verödet worden war, deuten darauf hin, daß eine olfaktorische Perzeption des Salzwassers stattfindet. Gelbaale waren im Seewasser negativ rheotaktisch. Sie zeigten im Süßwasser keinerlei rheotaktische Reaktionen im August, waren jedoch negativ rheotaktisch im Oktober, was auf jahreszeitlich unterschiedliche Aktivität hinweist und die bekannten saisonal bedingten Ortsveränderungen der Gelbaale erklären könnte. Seewasser, in dem vorher Blankaale gehalten worden waren, übte gegenüber Blankaalen keine stärkere Attraktivität aus als unbeeinflußtes Seewasser (Kontrollen), so daß sich für den Einfluß von Pheromonen keine positiven Hinweise ergeben. Die stärkste Bewegungsaktivität der Blankaale wurde zu den Zeiten natürlicher Dunkelheit beobachtet. Sie fällt in die Zeit zwischen Sonnenuntergang und Mondaufgang. Durch künstliche Veränderung der Hell-Dunkel-Periode konnten die Zeiten der Aktivität bis zu einem gewissen Grade verändert werden. Diese Ergebnisse werden hinsichtlich der Aalwanderung und lunarperiodischer Zusammenhänge diskutiert.
\end{abstract}

\section{INTRODUCTION}

This paper reports on an experimental investigation of rheotaxis and salinity preference as behavioural mechanisms which may contribute to the orientation of the American eel, Anguilla rostrata, during the initial portion of its catadromous migration. It describes the anticipatory nature of the salinity response, areas of similar and divergent behavior of the silver eel and the sexually immature yellow eel, a seasonal component to the orientation of yellow eels, suggests the use of olfaction for perception of seawater, and presents data on the relationship between diel locomotor activity of silver eels and the lunar period.

* Based on a thesis submitted in partial fulfillment of the requirements for the $\mathrm{Ph} . \mathrm{D}$. from University of Rhode Island, Kingston, Rhode Island. 
The problem was defined as follows: although the linear distance from Narragansett Bay to the spawning area is some $2200 \mathrm{~km}$, the work reported here deals only with that portion of the eel migration occurring in freshwater streams and at the interface between the freshwater and saltwater environments. Also, although it is generally recognized that portions of the eel population live in bays and estuaries, this paper examines only those eels migrating seaward from habitats in freshwater areas.

With regard to the life cycle of the American eel, as sexual maturity is approached, the eels undergo a series of physiological and morphological changes which culminate in the transformation of the freshwater yellow eel into the seagoing silver eel. The yellow eels are residents of lakes, streams, and estuaries for 8-10 years (BIEDER, 1971) before undergoing a metamorphosis which normally takes place in the autumn of the year. During this metamorphosis, the dorsal surface and pectoral fins are darkened, the ventral surface whitens, and the lateral surfaces assume a silver to coppery sheen. The eyes enlarge in diameter (WINN et al., 1975) and a coloration termed retinal gold appears in conjunction with a shift in the visual pigment toward deep-sea rhodopsin (WALD, 1958). Other conspicuous changes are the thickening of the skin and the accentuation of the lateral line. Internally, the gonads are developing, while the digestive system is possibly deteriorating. The above changes must be considered with respect to the fundamental characteristics of the metamorphic process (WALD, 1958). That is, a metamorphosis anticipates changes in the environment; it occurs in the old environment and is completed there; and it is a preparation for the new environment, and not a response to it.

MiLes (1968) suggests a celestial orientation for silver eels, which migrate from late August through November, at night during the dark of the moon, and often coincident with heavy rainfall (SMrth \& SAUnders, 1955, WINN \& HAMmen, 1969). The movement downstream is often highest during the early evening hours (WINN et al., 1975). European workers have shown generalized directional tendencies (Tesch \& LeLEK, 1973) and a lunar periodicity (BoEtius, 1967). Additional observations on the behaviour of $A$. anguilla, catch records, and fishermens reports, are reviewed by DEELDER (1970).

\section{METHODS AND MATERIALS}

Experiments to examine the orientation and behaviour of migratory eels were conducted in an outdoor enclosure on the campus of the University of Rhode Island's Graduate School of Oceanography, Narragansett, Rhode Island (Fig. 1), during the fall of 1971, 1972 and 1973. Adult eels on their seaward spawning migration were trapped in nearby streams: at the Hamilton fish ladder site on the Annaquatucket River, the Gilbert Stuart fish ladder site below the Pausacacao Pond outlet, and at the Wakefield fish ladder on the Saugatucket River. The eels were kept in freshwater holding tanks at the laboratory, and ranged in size from 20 to $70 \mathrm{~cm}$ for the silver eels and 10 to $34 \mathrm{~cm}$ for the yellow eels. Tests were most often made on the evening following capture, or at most, within several days. Approximately 1000 eels were tested in 35 trials constituting 14 experiments. After testing, the eels were measured, catalogued and either preserved or released. 
A $3.8 \mathrm{~m}$ Y-design choice chamber (Fig. 2) was used to test the eels' response to a series of experimental stimuli. The unit, shown also in plan view (Fig. 3), is designed for use in a variety of configurations and can be modified from one testing procedure to another. The chamber was placed such that the left arm pointed approximately east, the right arm south, and the base arm north.

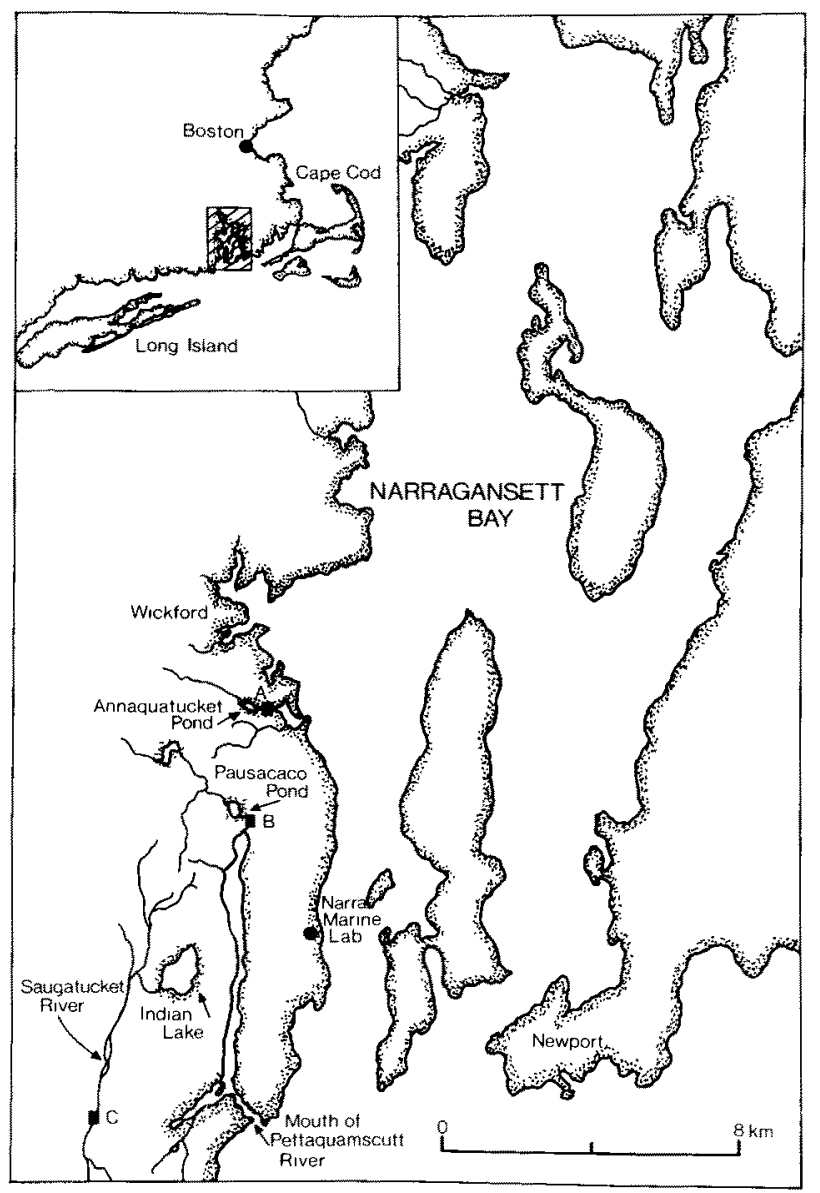

Fig. 1: Location of Narragansett Marine Laboratory and collection sites: (A) Hamilton fish ladder site on the Annaquatucket River; (B) Gilbert Stuart stream below fish ladder; (C) Wakefield fish ladder site on the Saugatucket River

For the rheotaxis experiments, the tank was filled at the outset, and became an essentially closed system. Water from the outflow at the terminal end of the base drained into a tank below it, from which it was recirculated by a $1 / 2$ HP sump pump into either of the other arms, while the third arm served as a "blank" with no flow. In order to avoid bias, on some occasions, the water was drained from either the left or the right arm and recirculated to the base arm. When the tank was used as a choice 
chamber, waters representing the stimuli were fed into two of the arms (usually the left and right arms) and passed through the center chamber and drained from the end of the third arm. Generally, the water source was introduced into an inflow arm at a rate of 38001 per hour, so that in a two-choice test, water flowed through the tank at $7600 \mathrm{l}$ per hour.

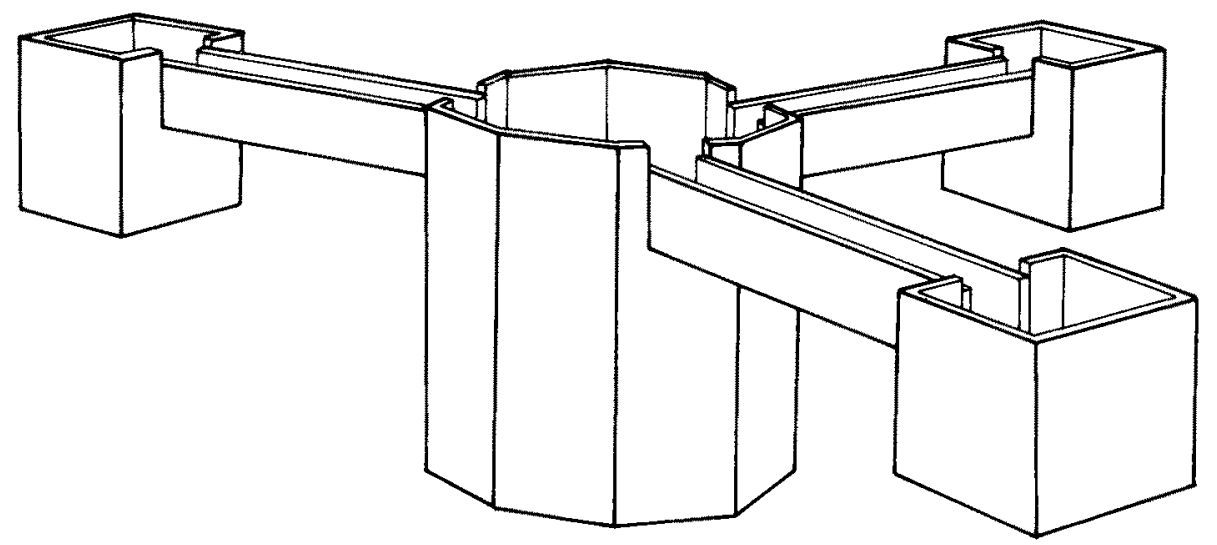

Fig. 2: Diagram of 3-arm choice chamber apparatus. Construction is of $1.9 \mathrm{~cm}$ plywood with polyester resin coated interior

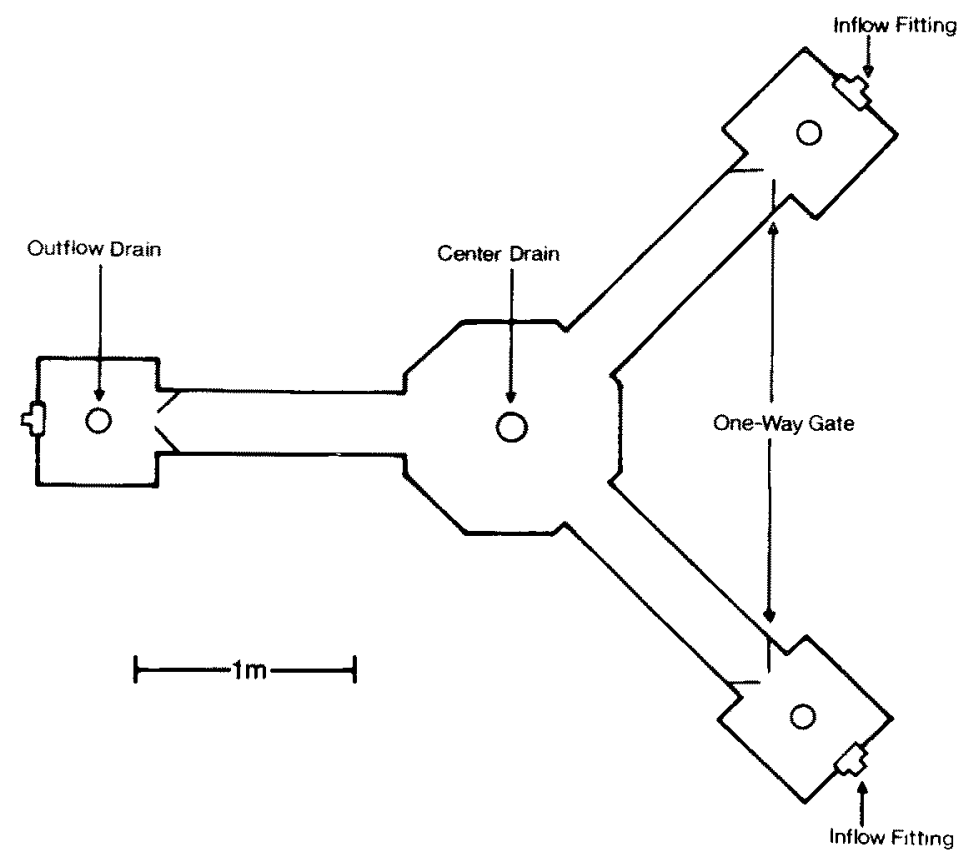

Fig. 3: Plan view of experimental tank. Inflow and drain fttings are $3.81 \mathrm{~cm} \mathrm{I.D.} \mathrm{PVC} \mathrm{with}$ a $5.08 \mathrm{~cm}$ I.D. center drain and standpipe 
Seawater used in these experiments was Narragansett Bay (30\% S) water. The local tap water used was artesian well water without chlorine, flouride, or other treatments. The natural stream water was pumped from the Annaquatucket River and transported to the laboratory in a truck equipped with a large stainless steel tank.

A single test was conducted in the following manner. The tank and plumbing were cleaned, flushed thoroughly, and then filled with either well water or natural stream water, depending on the experiment. Between 30-50 eels were taken from the holding tank, and placed into the center chamber of the Y-tank, and allowed to acclimate there for a period of several hours. Flow through the tank was begun at the initiation of the test. Scoring was a function of the number of eels that swam up into a given arm, through a one-way gate, and into the collecting chamber at the end of each arm. Each of the terminal collecting chambers was lined with a hardware cloth basket, so that an observer could efficiently and quietly obtain hourly counts by simply lifting out the basket and pouring the contained eels into a large plastic container. This gave both an hourly count and a total count for each arm during a given experiment. Except for a single experiment, each animal was used only once. A chi-square test (SIEGEL, 1956) was used to evaluate the test results.

The high-walled tank was set in an outdoor fenced enclosure, so that while the eels could see the sky overhead, they were essentially blocked from any other outside visual stimuli. Precautions were taken to prevent any imbalance other than the one being tested for. The tank arms were used alternately in any set of experiments.

The experiments performed were of the following types: (a) rheotaxis in well water: silver eels; (b) rheotaxis in natural stream water: silver and yellow eels; (c) choice between well water and Narragansett Bay water: silver eels; (d) choice between natural stream water and Narragansett Bay water: silver and yellow eels; (e) rheotaxis and salinity preference tests using heterogeneous samples of silver and yellow eels to observe, if possible, a difference; (f) experiments on salinity discrimination after olfactory ablation and controls for same: silver eels; $(\mathrm{g})$ test for presence of pheromones or socially significant exudates, and controls for same; (h) observations on the onset of locomotor activity as a function of light effects and lunar period.

\section{RESULTS}

When the tank was filled with well water, and the water recirculated from the drain arm back into one of the two inflow arms, silver eels in the center chamber were offered a choice between swimming upstream (positive rheotaxis), downstream (negative rheotaxis), and no current (neutral response). A strong negative rheotaxis was displayed (Table 1). In August, 1972, rheotaxis experiments using yellow eels in an identical recirculating system, but with natural streamwater, gave a distribution (Table 2) not different from that expected under the null hypothesis, which states that the response is equal for all choices. In similar rheotaxis experiments run two months later, during the migratory season, yellow eels in recirculated natural stream water displayed a strong negative rheotaxis (Table 3 ). In a final rheotaxis experiment, designed primarily to test the responses of silver eels in the natural stream situation, a heterogeneous sample of both yellow and silver eels was used. A negative rheotaxis 


\section{Table 1}

Distribution of silver eels in rheotaxis experiment with three choices (positive, negative or neutral rheotaxis) in a recirculating wellwater system. Compass direction (E, N, S) indicates approximate orientation of designated tank arm

\begin{tabular}{|c|c|c|c|c|c|}
\hline Date & Time (EST) & Total No. & $\begin{array}{c}\text { Inflow } \\
\text { (positive) }\end{array}$ & $\begin{array}{l}\text { No Flow } \\
\text { (neutral) }\end{array}$ & $\begin{array}{c}\text { Outflow } \\
\text { (negative) }\end{array}$ \\
\hline \multirow[t]{2}{*}{$\begin{array}{l}\text { October 7, } 1971 \\
\text { October } 8,1971\end{array}$} & $\begin{array}{l}1500-2020 \\
1800-2415\end{array}$ & $\begin{array}{l}56 \\
47\end{array}$ & $\begin{array}{l}3 \text { (E) } \\
1 \text { (E) }\end{array}$ & $\begin{array}{l}9(\mathrm{~N}) \\
6(\mathrm{~S})\end{array}$ & $\begin{array}{l}44(\mathrm{~S}) \\
40(\mathrm{~N})\end{array}$ \\
\hline & $\begin{array}{l}\text { Sums: } \\
\text { Mean: } \\
\chi^{2}\end{array}$ & $\begin{array}{c}103 \\
52 \\
109.54 \\
\end{array}$ & $\begin{array}{c}4 \\
2 \\
26.80\end{array}$ & $\begin{array}{c}15 \\
8 \\
10.88\end{array}$ & $\begin{array}{l}84 \\
42 \\
71.86\end{array}$ \\
\hline
\end{tabular}

Table 2

Distribution of yellow eels in rheotaxis experiment with natural stream water. Responses to the three choices demonstrated either positive, negative, or neutral rheotaxis. Compass direction $(E, N, S)$ indicates approximate orientation of tank arm

\begin{tabular}{|c|c|c|c|c|c|}
\hline Date & Time (EST) & Total No. & $\begin{array}{l}\text { Inflow } \\
\text { (positive) }\end{array}$ & $\begin{array}{l}\text { No Flow } \\
\text { (neutral) }\end{array}$ & $\begin{array}{l}\text { Outflow } \\
\text { (negative) }\end{array}$ \\
\hline \multirow{2}{*}{$\begin{array}{l}\text { August 2, } 1972 \\
\text { August } 3,1972\end{array}$} & $\begin{array}{l}1800-2200 \\
1800-2300\end{array}$ & $\begin{array}{r}8 \\
15\end{array}$ & 1 (S) & $\begin{array}{l}2(\mathrm{E}) \\
8(\mathrm{~S})\end{array}$ & $\begin{array}{l}5(\mathrm{~N}) \\
3(\mathrm{~N})\end{array}$ \\
\hline & $\begin{array}{l}\text { Sums: } \\
\text { Mean: } \\
\chi^{2}\end{array}$ & $\begin{array}{l}23 \\
8 \\
1.63 \\
\end{array}$ & $\begin{array}{l}5 \\
2 \\
1.13\end{array}$ & $\begin{array}{r}10 \\
3 \\
0\end{array}$ & $\begin{array}{l}8 \\
3 \\
0.5\end{array}$ \\
\hline
\end{tabular}

Table 3

Distribution of yellow eels in rheotaxis experiment with natural stream water. Responses to the three choices demonstrated either positive, negative, or neutral rheotaxis. Compass direction $(E, N, S)$ indicates approximate orientation of tank arm

\begin{tabular}{|cccccc|}
\hline Date & Time (EST) & Total No. & $\begin{array}{c}\text { Inflow } \\
\text { (positive) }\end{array}$ & $\begin{array}{c}\text { No Flow } \\
\text { (neutral) }\end{array}$ & $\begin{array}{c}\text { Outflow } \\
\text { (negative) }\end{array}$ \\
\hline October 1, 1973 & $1900-2000$ & 15 & $4(\mathrm{E})$ & $4(\mathrm{~S})$ & $7(\mathrm{~N})$ \\
October 2,1973 & $1900-2000$ & 10 & $5(\mathrm{~S})$ & $1(\mathrm{E})$ & $4(\mathrm{~N})$ \\
October 5, 1973 & $1900-2000$ & 23 & $6(\mathrm{E})$ & $3(\mathrm{~S})$ & $14(\mathrm{~N})$ \\
October 8, 1973 & $1900-2000$ & 48 & $11(\mathrm{~S})$ & $7(\mathrm{E})$ & $30(\mathrm{~N})$ \\
& Sum: & 96 & 26 & 15 & 55 \\
& Mean: & 32 & 9 & 5 & 18 \\
& $\chi^{2}$ & 26.69 & 1.13 & 9.03 & 16.53 \\
& & \multicolumn{4}{|l}{} \\
$\chi^{2}$ is the underlined value, partial contributing values are also shown for each cell.
\end{tabular}

was indicated for both stages (Table 4). Inspection of the data and associated $\chi^{2}$ values for Tables 3 and 4 suggests the two stages do not differ significantly in this response. 
Behaviour of migratory eels

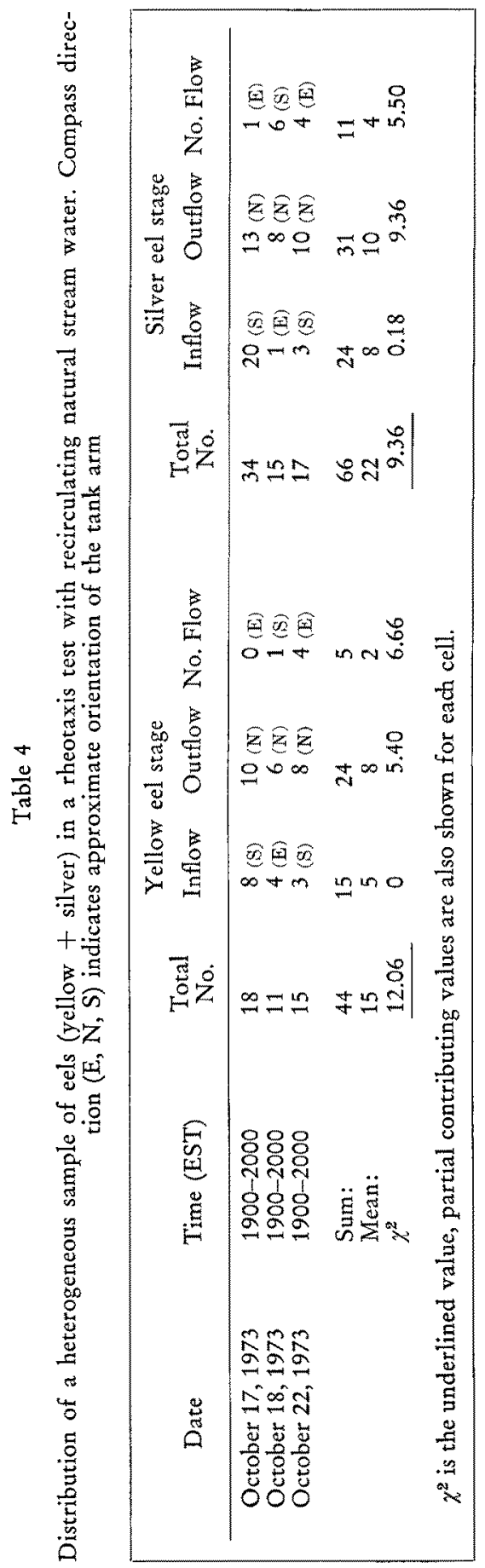




\section{Table 5}

Distribution of silver eels in salinity preference experiment with three choices: saltwater inflow, wellwater inflow, and the mixed outflow. Compass direction $(E, N, S)$ indicates approximate orientation of tank arm. Due to the different densities of salt- and freshwater inflows, wedged structure diagrammed in Figure 4 occurs in inflow arms

\begin{tabular}{|c|c|c|c|c|c|}
\hline Date & Time (EST) & Total No. & $\begin{array}{l}\text { Fresh } \\
\text { inflow }\end{array}$ & $\begin{array}{c}\text { Salt } \\
\text { inflow }\end{array}$ & Outflow \\
\hline $\begin{array}{l}\text { October } 14,1971 \\
\text { October } 19,1971 \\
\text { October } 20,1971 \\
\text { October } 22,1971\end{array}$ & $\begin{array}{l}1900-2200 \\
1830-2330 \\
1830-2400 \\
1830-0100\end{array}$ & $\begin{array}{l}42 \\
21 \\
17 \\
21\end{array}$ & $\begin{array}{l}1(\mathrm{E}) \\
2(\mathrm{E}) \\
2(\mathrm{~S}) \\
3(\mathrm{~S})\end{array}$ & $\begin{array}{l}39(\mathrm{~S}) \\
16(\mathrm{~S}) \\
13(\mathrm{E}) \\
15(\mathrm{~N})\end{array}$ & $\begin{array}{l}2(\mathrm{~N}) \\
3(\mathrm{~N}) \\
2(\mathrm{~N}) \\
3(\mathrm{E})\end{array}$ \\
\hline & $\begin{array}{l}\text { Sum: } \\
\text { Mean: } \\
\chi^{2}\end{array}$ & $\begin{array}{r}101 \\
25 \\
108.48 \\
\end{array}$ & $\begin{array}{c}8 \\
2 \\
19.57\end{array}$ & $\begin{array}{l}83 \\
21 \\
72.27\end{array}$ & $\begin{array}{l}10 \\
2 \\
16.64\end{array}$ \\
\hline
\end{tabular}

Table 6

Distribution of silver eels in a salinity preference experiment where the three choices were: saltwater inflow, wellwater inflow, and the mixed outflow. Dams installed at base of arms prevented wedge or counterflow structure, and gave homogeneous stimulus diagrammed in

Figure 5. Compass direction (E, N, S) indicates approximate orientation of tank arm

\begin{tabular}{|llcccc|}
\hline Date & Time (EST) & Total No. & $\begin{array}{c}\text { Fresh } \\
\text { inflow }\end{array}$ & $\begin{array}{c}\text { Salt } \\
\text { inflow }\end{array}$ & Outflow \\
\hline October 27, 1971 & $1720-2300$ & 26 & $1(\mathrm{~S})$ & $21(\mathrm{E})$ & $4(\mathrm{~N})$ \\
October 29, 1971 & $1800-2300$ & 16 & $0(\mathrm{~S})$ & $15(\mathrm{E})$ & $1(\mathrm{~N})$ \\
November 5, 1971 & $1700-1915$ & 49 & $3(\mathrm{E})$ & $37(\mathrm{~N})$ & $9(\mathrm{~N})$ \\
& Sum: & 91 & 4 & 73 & 14 \\
& Mean: & 30 & 1 & 24 & 5 \\
& $\chi^{2}$ & 91.68 & 22.86 & 60.03 & 8.79 \\
\hline
\end{tabular}

$\chi^{2}$ is the underlined value, partial contributing values are also shown for each cell.

Table 7

Distribution of yellow eels in salinity preference experiment with three choices: saltwater inflow, natural streamwater inflow, and the mixed outflow. Dams at base of tank arms gave a homogeneous stimulus and prevented the wedged or counterflow structure associated with water masses of different densities. Compass direction $(E, N, S)$ indicates approximate orientation of tank arm

\begin{tabular}{|llcccc|}
\hline \multicolumn{1}{|c}{ Date } & Time (EST) & Total No. & $\begin{array}{c}\text { Fresh } \\
\text { inflow }\end{array}$ & $\begin{array}{c}\text { Salt } \\
\text { inflow }\end{array}$ & Outflow \\
\hline October 9, 1973 & $1910-2000$ & 43 & $18(\mathrm{E})$ & $14(\mathrm{~S})$ & $11(\mathrm{~N})$ \\
October 11,1973 & $1900-2000$ & 33 & $6(\mathrm{~S})$ & $15(\mathrm{E})$ & $12(\mathrm{E})$ \\
November 15, 1973 & $1800-1900$ & 15 & $4(\mathrm{E})$ & $3(\mathrm{~S})$ & $8(\mathrm{~N})$ \\
& Sum: & 91 & 28 & 32 & 31 \\
& Mean: & 30 & 9 & 11 & 10 \\
& $\chi^{2}$ & 0.29 & 0.13 & 0.13 & 0.03 \\
\hline
\end{tabular}

$\chi^{2}$ is the underlined value, partial contributing values are also shown for each cell. 
Behaviour of migratory eels

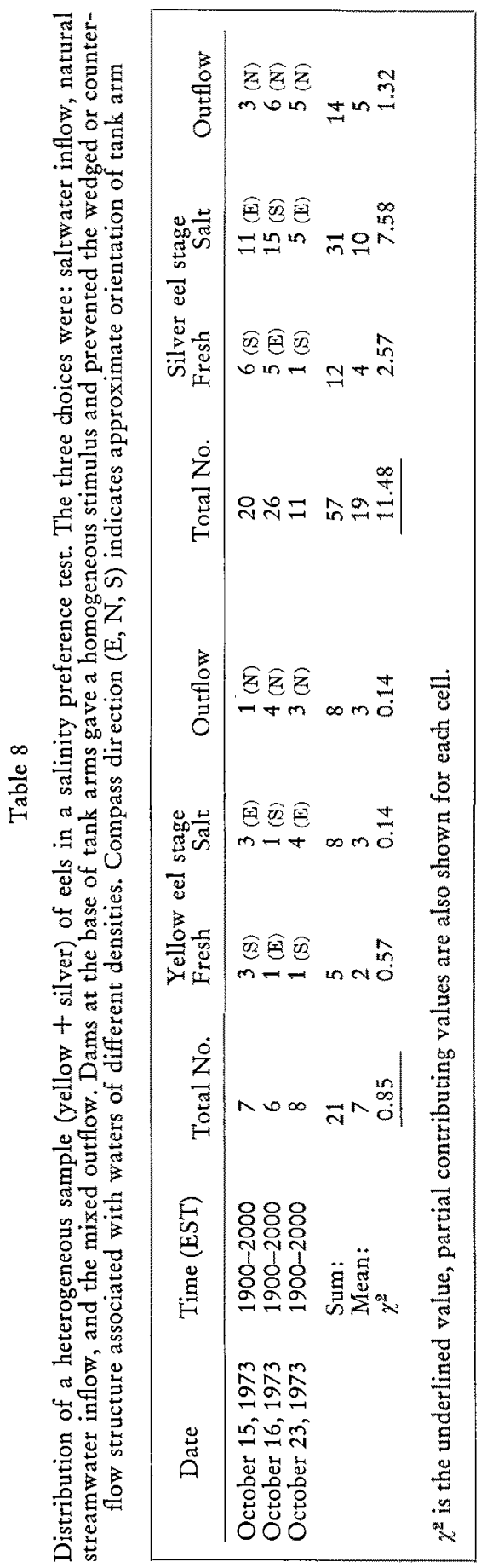



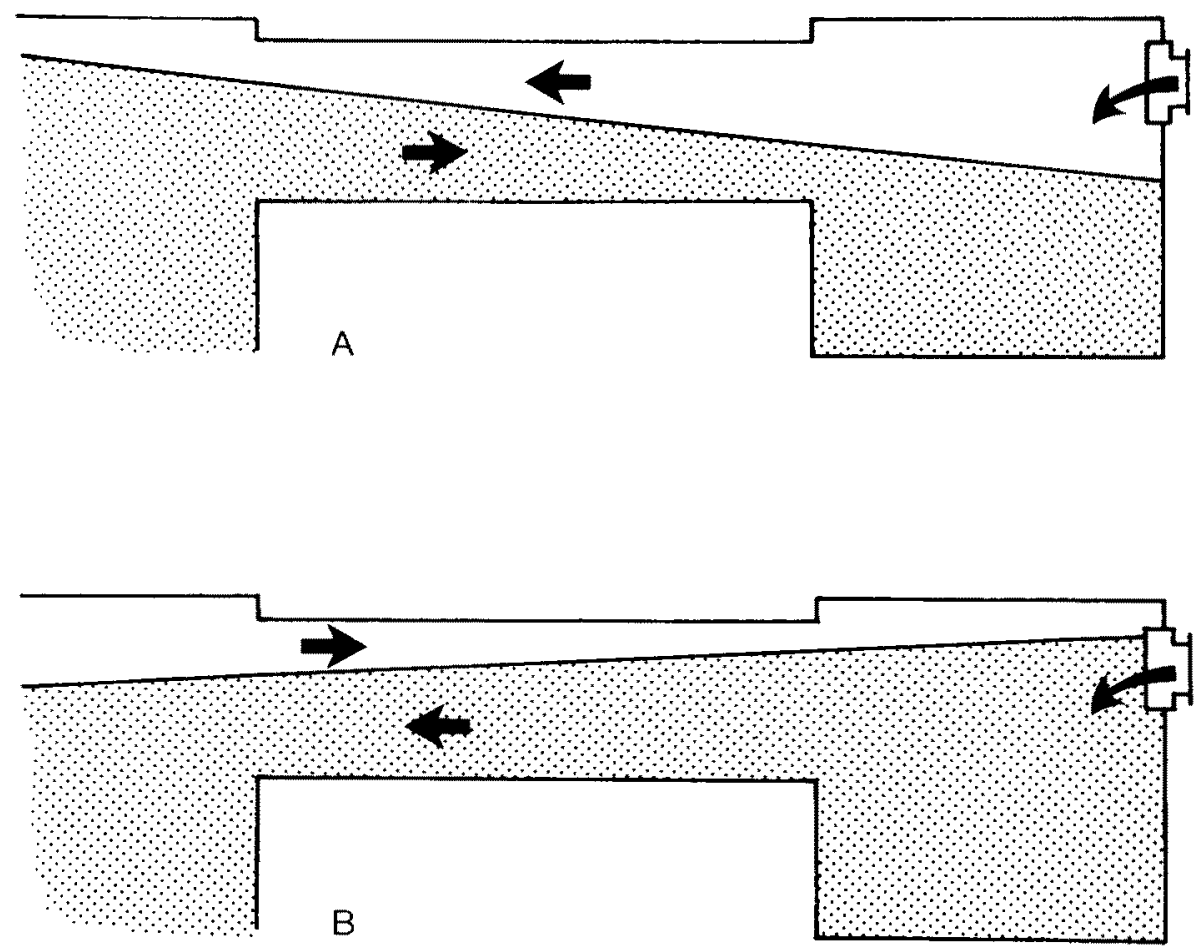

Fig. 4: Wedge or counterflow structure created in test tank by different density water masses. (A) freshwater inflow develops saltwater wedge underneath. (B) saltwater inflow develops freshwater counterflow on top

When salt water was introduced into the tank as one of the two inflow choices (well water being the other), the sign of the rheotaxis reversed, and the silver eels swam into the saltwater inflow (Table 5). In these experiments, flow tests showed that, due to the difference in the densities of the two water masses used as inflow stimuli, the water in the two upstream arms developed a "wedge"configuration as shown in Figure 4 . In the freshwater inflow arm, a saltwater counterflow developed underneath, while in the saltwater inflow arm, a freshwater counterflow lay over the surface. To avoid this situation, and give a more homogeneous stimulus, dams were installed at the base of the tank arms (Fig. 5). The dams seemed not to impede the movement of the eels, and in the revised saltwater versus freshwater trials, silver eels again decidedly chose the saltwater inflow (Table 6). The dams were used in all further saltwater vs. freshwater tests.

In a salinity preference experiment using yellow eels, a preference was not shown, and the 91 animals in 3 trials were distributed randomly among the three choices (Table 7). In this test, natural stream water was used as the freshwater stimulus.

In the salinity vs. natural freshwater test designed primarily to observe the responses of silver eels, the heterogeneous sample also included yellow eels. A segrega- 

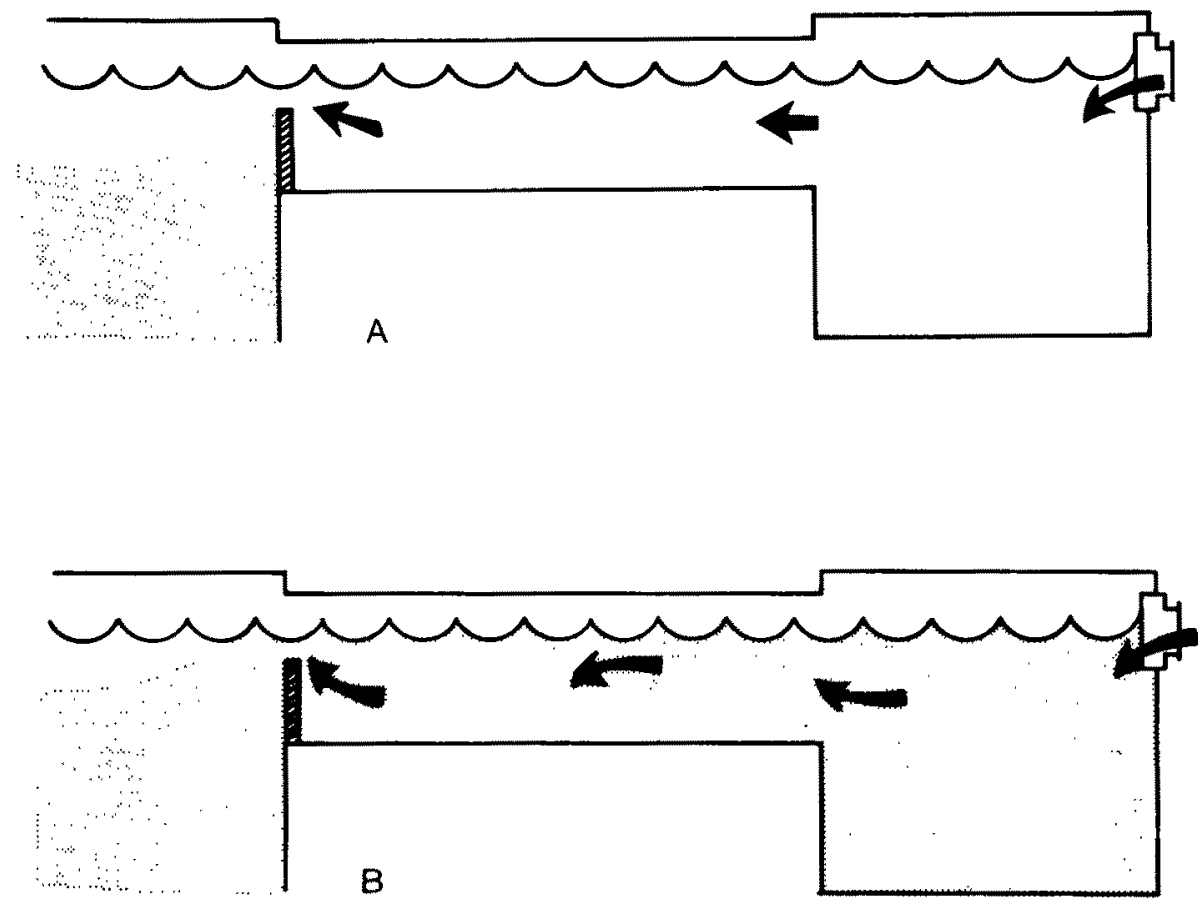

Fig. 5: Dams installed at base of arms give homogeneous stimulus and prevent counterflows normally developed by water masses of different densities. (A) freshwater inflow. (B) saltwater inflow

tion by response between the two stages was evident as the silver eels swam in the direction of the seawater inflow, while the yellow eels remained randomly distributed (Table 8).

To determine the possible involvement of olfaction in salinity preference by silver eels, animals subjected to cauterization of the olfactory capsules were exposed to the saltwater vs. wellwater choice previously described. The results for the three-way choice were nonrandom at the $95 \%$ confidence level (Table 9). Examination of the partial, or contributing, values to the calculation from each cell indicates a tendency toward the outflow area, or a display of negative rheotaxis. In a control experiment for the olfactory ablation study, a single olfactory capsule was cauterized on each animal. In this way, the eel might be subjected to a comparable stress or trauma, but still possess an olfactory capability. Results indicated a distinct salinity preference (Table 10). In an additional control, blinded silver eels were exposed to the saltwater versus wellwater choice. The eels again displayed the preference for saltwater (Table 11), but a tendency for the outflow arm, a negative rheotaxis, was also seen.

Since large numbers of eels were being tested simultaneously, it was necessary to determine whether the animals were acting independently and responding to the stimuli on an individual basis, or whether some eels might be following others, or 
somehow reacting to the presence of other animals. Before testing for pheromones or socially significant exudates, a control was run where silver eels were exposed to a choice of two identical saltwater inflows. A uniform distribution between the two saltwater arms resulted (Table 12), with again a strong positive rheotaxis to the saltwater stimulus. The possible presence of pheromones or attractants was then tested by placing 10 silver eels in a hardware cloth basket at the head of one of the inflow arms under the identical experimental configuration as in the control. Inflowing salt water in one of the choice arms passed over the eels before flowing down the arm into the center chamber area. There was no discrimination between this stimulus and the arm containing no eels, as the two saltwater arms remained similar in their attractiveness, to each other (Table 13) and to the control.

The onset of locomotor activity on any given day in the experimental tank was observed to take place primarily within the first two hours of darkness following sunset. During a period around new moon, total hourly counts for eels moving out of the center chamber and up into the collecting baskets were plotted against time in hours after sunset (Fig. 6). The activity was peaked in the first two hours following sunset, and movement was completed before midnight. On an evening three nights after a full moon, when the moon's illumination might be bright enough to inhibit eel movement, the highly peaked activity was again observed (Fig. 7). The night was

Table 9

Distribution of silver eels with cauterized olfactory capsules in a freshwater vs. saltwater discrimination test. Compass direction $(E, N, S)$ indicates approximate orientation of tank arm

\begin{tabular}{|c|c|c|c|c|c|}
\hline Date & Time (EST) & Total No. & $\begin{array}{l}\text { Fresh } \\
\text { inflow }\end{array}$ & $\underset{\text { inflow }}{\text { Salt }}$ & Outflow \\
\hline \multirow[t]{2}{*}{$\begin{array}{l}\text { November } 8,1971 \\
\text { November } 9,1971 \\
\text { November } 10,1971\end{array}$} & $\begin{array}{l}1630-1915 \\
1615-1930 \\
1620-2230\end{array}$ & $\begin{array}{l}18 \\
45 \\
29\end{array}$ & $\begin{array}{r}6(\mathrm{E}) \\
11(\mathrm{~S}) \\
3(\mathrm{E})\end{array}$ & $\begin{array}{r}6(\mathrm{~S}) \\
18(\mathrm{E}) \\
6(\mathrm{~S})\end{array}$ & $\begin{array}{l}6(\mathrm{~N}) \\
16(\mathrm{~N}) \\
20(\mathrm{~N})\end{array}$ \\
\hline & $\begin{array}{l}\text { Sum: } \\
\text { Mean: } \\
\chi^{2}\end{array}$ & $\begin{array}{l}92 \\
31 \\
7.83 \\
\end{array}$ & $\begin{array}{l}20 \\
7 \\
3.90\end{array}$ & $\begin{array}{l}30 \\
10 \\
0.03\end{array}$ & $\begin{array}{l}42 \\
14 \\
3.90\end{array}$ \\
\hline
\end{tabular}

Table 10

Control experiment for olfactory ablation study. Distribution of silver eels with olfactory capsules cauterized on one side only, in a freshwater vs. saltwater discrimination test. Compass direction $(\mathrm{E}, \mathrm{N}, \mathrm{S})$ indicates approximate orientation of designated tank arm

\begin{tabular}{|cccccc|}
\hline Date & Time (EST) & Total No. & $\begin{array}{c}\text { Fresh } \\
\text { inflow }\end{array}$ & $\begin{array}{c}\text { Salt } \\
\text { inflow }\end{array}$ & Outflow \\
\hline November 11, 1971 & $1700-1900$ & 33 & $3(\mathrm{~S})$ & $16(\mathrm{E})$ & $14(\mathrm{~N})$ \\
& $\chi^{2}$ & 8.91 & 5.82 & 2.27 & 0.82 \\
\multicolumn{4}{l}{$\chi^{2}$ is the underlined value, partial contributing values are also shown for each cell. } \\
\hline
\end{tabular}


clear, cold, and quite dark for two full hours before a bright, full moon rose over the horizon. This peaked activity was further shown on three nights around a lunar $3 \mathrm{rd}$ quarter, when the moon rose later in the evening (Fig. 8). The above are contrasted to the events during a lunar 1st quarter when the moon rose around noon and set around

\section{Table 11}

Control experiment for olfactory ablation study. Distribution of blinded silver eels in a freshwater vs. saltwater discrimination test. Compass direction (E, N, S) indicates approximate orientation of tank arm

\begin{tabular}{|c|c|c|c|c|c|}
\hline Date & Time (EST) & Total No. & $\begin{array}{l}\text { Fresh } \\
\text { inflow }\end{array}$ & $\begin{array}{c}\text { Salt } \\
\text { inflow }\end{array}$ & Outflow \\
\hline \multirow[t]{2}{*}{ November 19,1971} & $\begin{array}{l}1200-1820 \\
\text { (tank covered) }\end{array}$ & 37 & 3 (E) & $15(\mathrm{~S})$ & $19(\mathbb{N}\rangle$ \\
\hline & $\chi^{2}$ & 11.27 & 7.03 & 0.59 & 3.65 \\
\hline
\end{tabular}

Table 12

Control experiment for pheromone test. Distribution of silver eels in tank with two identical saltwater inflows. Compass direction $(\mathrm{E}, \mathrm{N}, \mathrm{S}$ ) indicates approximate orientation of tank arm

\begin{tabular}{|c|c|c|c|c|c|}
\hline Date & Time (EST) & Total No. & $\begin{array}{c}\text { Salt } \\
\text { inflow }\end{array}$ & $\begin{array}{c}\text { Salt } \\
\text { inflow }\end{array}$ & Outflow \\
\hline November 16, 1971 & $\begin{array}{l}1445-1600 \\
\text { (tank covered) }\end{array}$ & 37 & $8(\mathrm{~N})$ & $14(S)$ & $15(\mathrm{E})$ \\
\hline \multirow[t]{2}{*}{$\begin{array}{l}\text { November } 16,1971 \\
\text { November } 17,1971\end{array}$} & $\begin{array}{l}1645-1930 \\
1445-1750 \\
(\operatorname{tank} \text { covered) }\end{array}$ & $\begin{array}{l}22 \\
37\end{array}$ & $\begin{array}{r}8(\mathrm{~N}) \\
18 \stackrel{(\mathrm{N})}{ }\end{array}$ & $\begin{array}{r}6(S) \\
17(S)\end{array}$ & $\begin{array}{l}8(E) \\
2(N)\end{array}$ \\
\hline & $\begin{array}{l}\text { Sum: } \\
\text { Mean: } \\
\chi^{2}\end{array}$ & $\begin{array}{l}96 \\
32 \\
1.19 \\
\end{array}$ & $\begin{array}{l}34 \\
11 \\
0.13\end{array}$ & $\begin{array}{l}37 \\
12 \\
0.78\end{array}$ & $\begin{array}{l}25 \\
8 \\
0.28\end{array}$ \\
\hline
\end{tabular}

Table 13

Distribution of silver eels in an experiment designed to investigate the effect of possible pheromones or exudates on the responses of individual eels in the test tank. One of two identical saltwater intlows washed over a basket containing 10 live eels before entering the tank arm. Compass direction $(E, N, S)$ indicates approximate orientation of tank arm

\begin{tabular}{|clcccc|}
\hline Date & Time (EST) & Total No. & $\begin{array}{c}\text { Salt inflow } \\
\text { with eels }\end{array}$ & $\begin{array}{c}\text { Salt inflow } \\
\text { w/o eels }\end{array}$ & Outflow \\
\hline November 15, 1971 & $1630-1800$ & 44 & $10(\mathrm{~N})$ & $17(\mathrm{~S})$ & 11 (E) \\
November 18, 1971 & $1200-1730$ & 37 & $15(\mathrm{~S})$ & $10(\mathrm{E})$ & 11 (N) \\
& Sum: & 81 & 25 & 27 & 22 \\
& Mean: & 40 & 13 & 14 & 11 \\
& $\chi^{2}$ & 0.51 & 0.01 & 0.22 & 0.29 \\
\cline { 2 - 5 } & & &
\end{tabular}




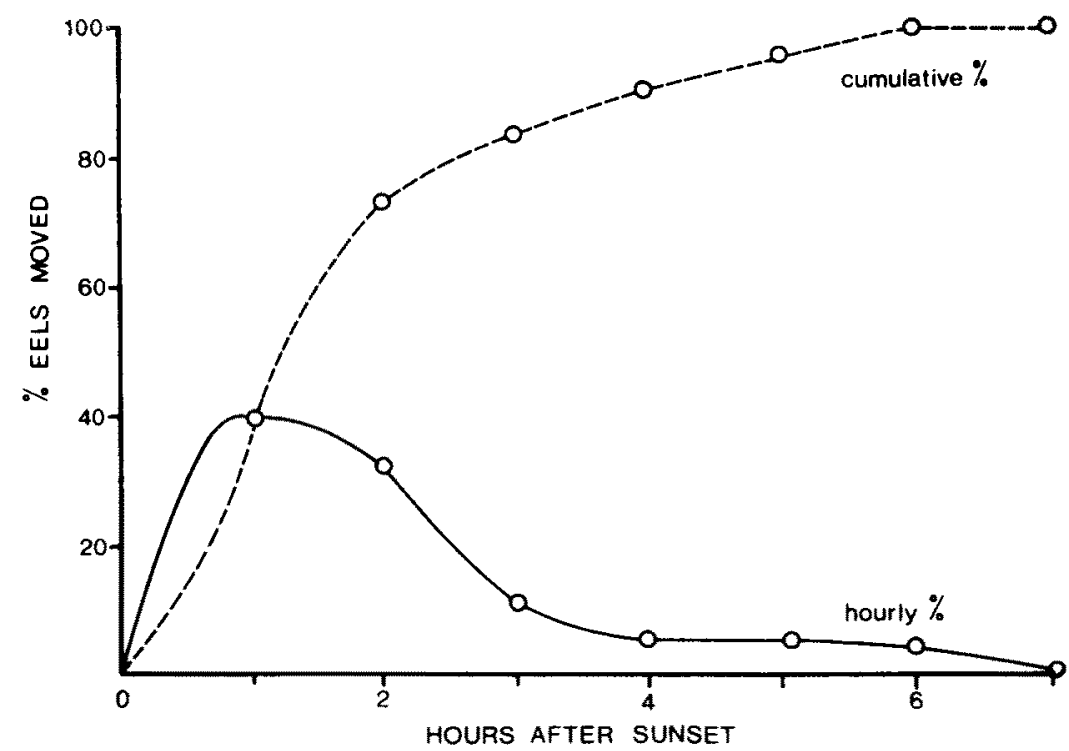

Fig. 6: Percent mean locomotor activity in the hours after sunset on four nights following a new moon, October 1971. Total number of eels tested $=108$

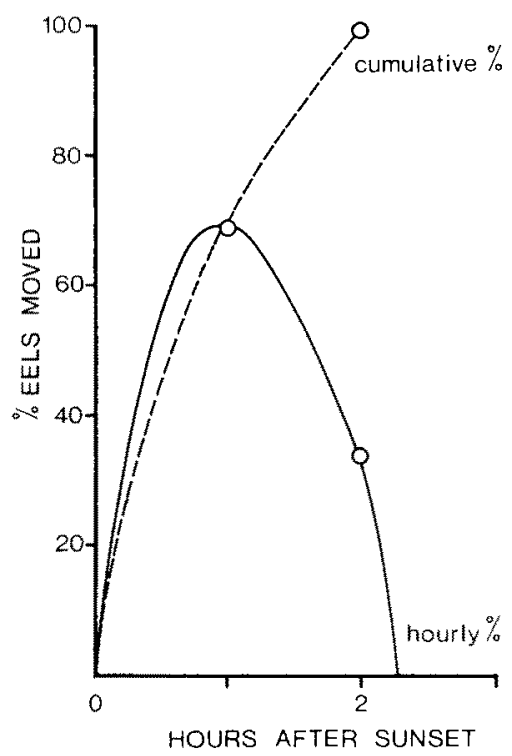

Fig. 7: Percent mean locomotor activity in the hours after sunset on an evening three days following the full moon, November 1971. Total number of eels tested $=48$ 


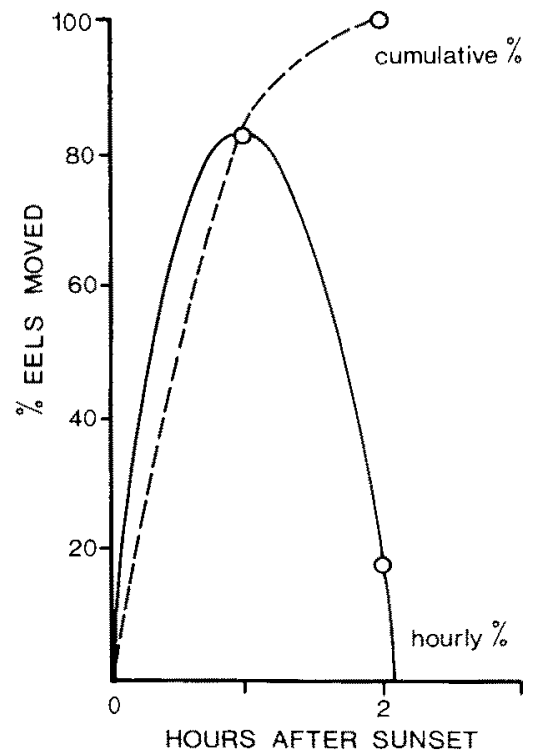

Fig. 8: Percent mean locomotor activity in the hours after sunset on three consecutive nights (preceding, on, and following) around a 3rd quarter moon, November 1971. Total number of eels tested $=86$

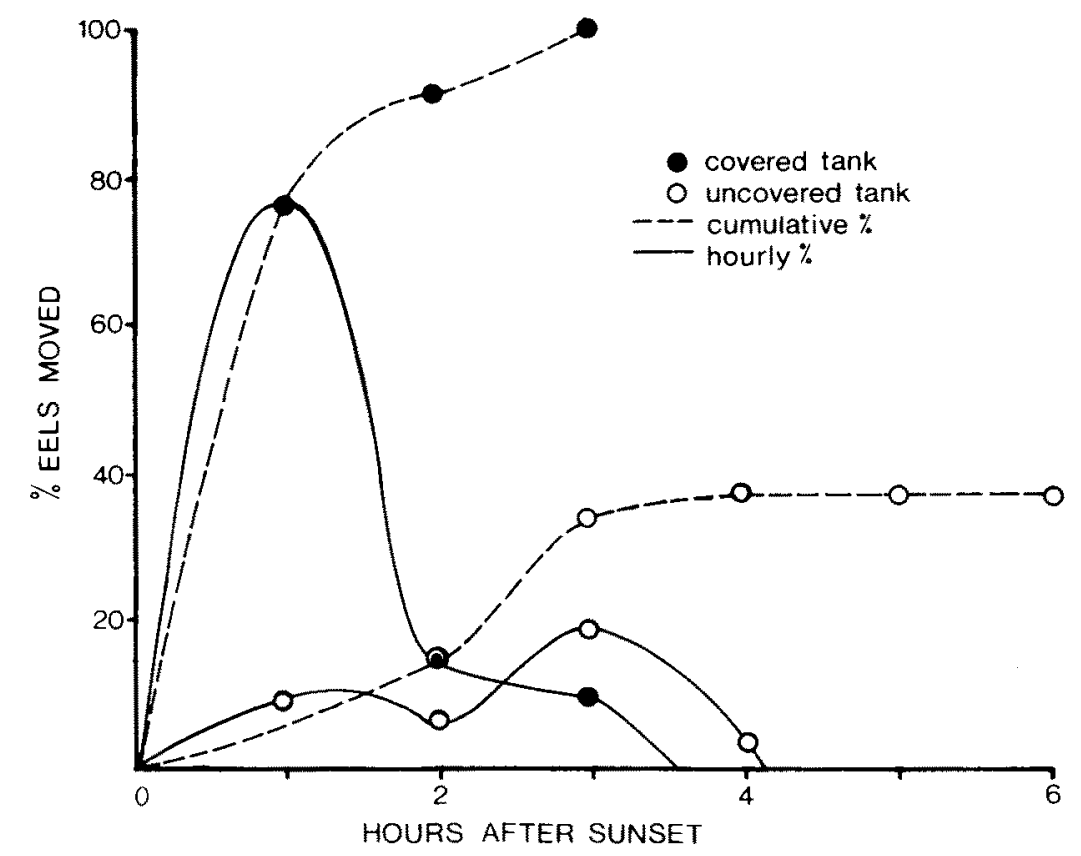

Fig. 9: Comparison of percent mean locomotor activity in the hours after sunset for eels under open sky (uncovered tank) and in a covered tank. Experiments conducted on two nights directly following a 1st quarter moon, October 1971. Total number of eels tested was 32 (tank uncovered) and 21 (tank covered) on the night following 


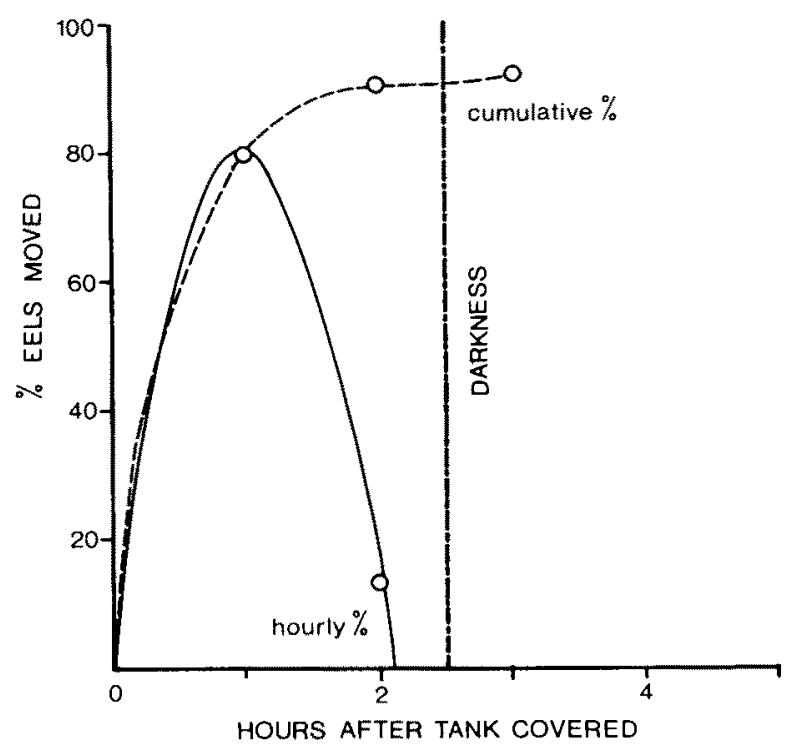

Fig. 10: Percent mean locomotor activity during daylight hours in tank fitted with opaque cover at $1500 \mathrm{~h}$

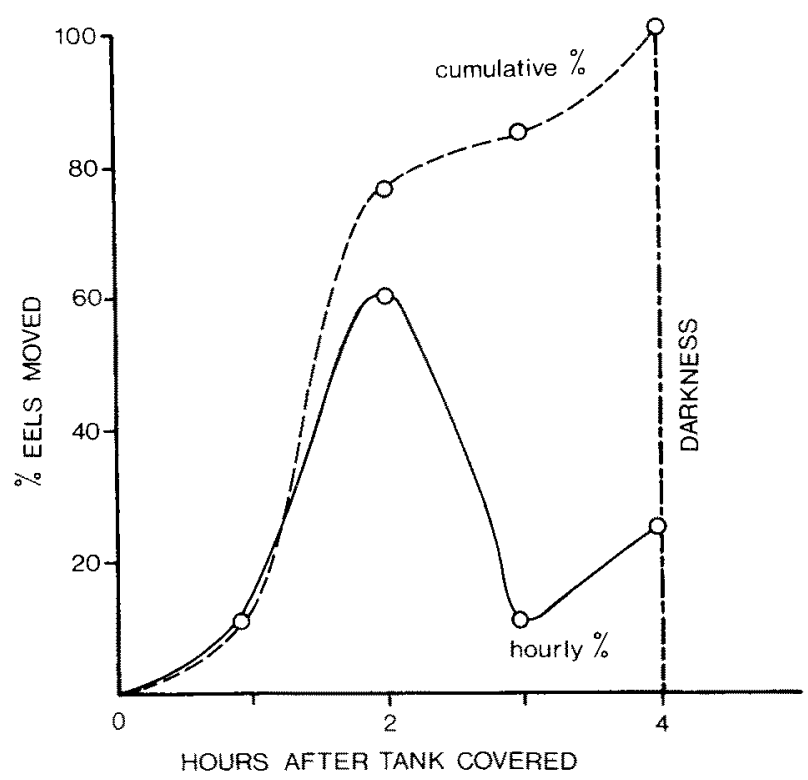

Fig. 11: Percent mean locomotor activity during daylight hours for tank fitted with opaque cover at $1330 \mathrm{~h}$ 
midnight. During the early evening hours, the moon was high and bright. In fact, the sky never did completely darken. On this night, the movement of the eels seemed to be retarded, with only $25 \%$ of the eels moving out within the first two hours following sunset, $37 \%$ after four hours, and no additional movement in two additional hours, during which the moon had continued to rise (Fig. 9). On the following night, an identical experiment was run using the same lot of eels (unfortunately, some had escaped), with a black polyethylene cover fitted on the tank shortly after sunset. Under these conditions, the characteristic peaked activity returned, and $90 \%$ of the eels had moved within the initial two hours (Fig. 9). The center chamber was emptied of eels within one additional hour.

To determine if locomotor activity could be artificially induced during daylight hours, on two days, the cover was installed on the tank at $1500 \mathrm{~h}$, approximately $21 / 2$ hours before darkness would normally occur. Locomotion began, and $94 \%$ of the eels had moved into the collecting area within two hours, before normal darkness (Fig. 10). In an additional test, the tank was covered at $1330 \mathrm{~h}$, or four hours before natural darkness. $67 \%$ of the eels moved in the first two hours, and all eels moved before the onset of normal darkness (Fig. 11), although the overall activity appeared not to be as peaked. In all cases the tests were actually begun, and the flows started, $11 / 2$ hours prior to covering the tank. In all tests, no eels moved off the bottom of the tank during this period.

\section{DISCUSSION}

European silver eels migrating in inland waters are strongly influenced by the flow of water and generally tend to swim with the current if one exists (DeELDER, 1954). DEELDER (1954) also stated that in rivers the silver eel moves only towards the sea, and no silver eel has ever been seen swimming upstream. This study has demonstrated a negative rheotaxis in freshwater flows for Anguilla rostrata under experimental conditions, where many of the extraneous stimuli which exist in the field are absent. Also, my notes corroborate the field observations of LowE (1952) on $A$. anguilla that the migrating silver eels swim headfirst downstream, so that they travel faster than the current. Using this negative rheotaxis, the downstream migrant reaches the inner estuarine region, where it encounters an environment very different from the river. According to fishermen's allegations (DeEcDer, 1970), European silver eels in freshwater are greatly stimulated by inflowing sea water and may tend to swim against a sea water flow. The data reported here are a result of the first experimentalinvestigation of this response. The presentation of the saltwater/freshwater stimuli in a wedge configuration may be analagous to the situation encountered by the eels at the freshwater/brackish water interface. The arm with the saltwater inflow beneath a freshwater counterflow resembles the situation met by eels moving out of stream mouths into an estuary. In response to a saltwater inflow, my data indicate the silver eels reversed the sign of their freshwater rheotaxis. Further tests, in which a twolayered system was not allowed to develop, also resulted in a preference for salt water over either well water or natural stream water by silver eels, in homogeneous samples 
and in heterogeneous samples containing yellow eels. This means that in nature, regardless of their swimming depth, silver eels migrating seaward in an estuary are appropriately guided by their rheotactic responses - negative in the outflowing fresh surface layers, and positive in the inflowing, deeper, more saline water. The salinity response is noteworthy in that the eels netted in freshwater streams have not been exposed to salt water for some time, possibly during their entire feeding, or yellow eel, stage. This behavioral response, then, is in anticipation of a step which will be encountered along the animals' migratory route and should provide the necessary orientation for the eels' directed travel through an environmental transition zone. Once solidly into salt water, other stimuli will help shape their course.

A behaviorally preadapted salinity preference has previously been demonstrated for several species of anadromous fishes. When the salinity preference of sticklebacks and juvenile salmon was studied on a year-round basis, the beginning and end of the migratory season were characterized by changes in salinity preference (BAGGERMAN, 1957, 1960). Specifically, the threespined stickleback, Gasterosteus aculeatus, migrates from salt to fresh water early in the year, and demonstrates a freshwater preference at that time. At the end of the breeding season, the stickleback migrates back to the sea, and from that time until the next spring shows a preference for salt water. Similar results were obtained for several species of juvenile Pacific salmon, Oncorbyncus (Baggerman, 1960; Otto \& McInerney, 1970). After observing a temporal change in salinity preference from fresh water through increasing sea water concentrations to open ocean salinities, McINERnEy (1964) proposed that juvenile Pacific salmon are able to use estuarial salinity gradients as one of the directive cues in their seaward migration. The above studies showed a correlation between thyroid activity and salinity preference, and of interest to the present work, established the anticipatory nature of this physiological-behavioral migratory condition or readiness.

The salinity preference reported here may be part of a behavior analagous to the sequential hypothesis for home-stream detection proposed for salmon by HARDEN JoNEs (1968). The behavioral responses and migratory orientation of the eel may be arranged in ordered sequential steps. In this way, orientation is tailored to the environment for a given time and set of conditions, and is efficient at guiding the eel through a portion of the migration. This thinking might pertain to the work of MrLes (1968) where a celestial orientation mechanism was suggested for eels taken from streams in Nova Scotia. While celestial orientation may well play a role in open-sea migration, it is most probably not a primary mechanism in inland and inshore areas, where a rheotaxis-salinity preference mechanism is a more obvious and biologically efficient choice. Support for the sequential arrangement of orientation responses comes from the work of TESCH (1974), which suggests an orientation with respect to the earth's magnetic field, which is only found after the migrating eels have entered the saline waters of the North Sea. In short, the behavioral repertoire of the eel may include any number of orientation responses, of which only one may be in a position of primary alignment in response to, or anticipation of, a given set of environmental stimuli. In this light, the relationship between behavioral adaptations and the changing environment encountered on the migration is somewhat clarified.

Experiments to investigate the sensory receptor responsible for the salinity re- 
sponse of the eel suggest an olfactory mechanism. Ablation of the olfactory capsule was done by cold cautery, and there seems little chance that any reception remained. After ablation, orientation of the eels became nearly random, with a slight tendency to revert to the initial negative rheotaxis observed in experiments. Although trauma introduced by the operation may have an effect (PETERS, 1971), comparable trauma introduced through cautery of one olfactory capsule, or blinding, did not prevent the eels from making a non-random salinity choice. However, even though the distinction between smell and taste seems to be somewhat less pronounced in fish than in higher vertebrates (BARDACH et al., 1967), one might expect that since an olfactory mechanism is suggested, the eel responded to an odorous component in the sea water rather than to the salt itself, which might be tasted.

Since experiments to test for the possible presence of pheromones or other exudates with social significance were negative, it is suggested that the samples of eels were made up of individuals independently responding to the stimuli presented in the test tank.

The difference in the neutral response of the yellow eels tested in August compared to the strong negative rheotaxis of those tested in October seems to suggest the possibility of a seasonal component involved in the orientation behavior of yellow eels. One might conclude that for the greater part of the year, yellow eels lack rigid orientation tendencies and establish a residence without conspicuous behavioral drives toward extended excursions or migrations. GunNing \& SHOOP (1962) concluded that eels occupying the headwater regions of streams exhibit restricted movements, and that the home range of the eels observed was on the order of 200 linear feet, or less, of stream. The suggestion of homing by VLADYKov (1971) would seem to corroborate the above. A home-range tendency was likewise indicated for Anguilla anguilla by Mann (1964) and Tesch (1967). However, during certain times of the year, yellow eels may display some restlessness or movement. Possibly this constitutes a "dry run" for the eventual offshore migration. Over a period of several migration seasons, a yellow eel might assume increasingly advanced stages of sexual maturity before finally firing off for the Sargasso Sea. After each false start, or trial run, the migratory characteristics will again wane, either totally or to a large degree, until the next migratory season. A movement of yellow eels is suggested by WINN et al. (1975), who report that yellow eels are caught more often during the same monthly periods in which silver eels are caught. Further, fishermen's reports collected by MEDCoF (1969) indicated a fall-upstream/spring-downstream movement for yellow eels. These results suggest some type of movement, although in opposition to the data and resulting speculation reported here. This difference can only be resolved by future work.

Finally, the non-orientation of the yellow eels in the fresh-versus saltwater test might indicate that the termination of the "dry run" movement is in the vicinity of the saltwater interface. This effect is known for coho salmon, Oncorbynchus kisutch, where the underyearlings remain in rivers, never progressing further than the upper estuarine region. Consistent with this behavior, their salinity preference never goes beyond $3 \% \mathrm{Cl}$ (MCINERnEY, 1964). Thus it may be that it is the response to salinity which contains the yellow eel in its feeding habitat as well as later guides the silver eel away from it. 
Although locomotor activity has been studied for sexually immature Anguilla rostrata (BOHUN \& WINN, 1966), no experimental data have been reported for the silver eel stage. Field data indicate that the migration of silver eels (Anguilla anguilla) takes place in the early hours of the night (Lowe, 1952), and that it occurs only between sunset and midnight (BRÄUTIGAM, 1961). With circumstances favorable to eel migration, BRÄUTIGAM (1961) observed that the main daily migration was concluded in the first period of nightly darkness, frequently in less than an hour. Data reported here corroborate the above field observations and indicate that the onset of locomotor activity in migratory silver eels ( $A$. rostrata) takes place in the first two hours of darkness following sunset. This conclusion is well supported by field data, which included hourly tallies recorded on an electronic fish counter, from the same river in which I collected eels (WINN et al., 1975).

What causes this periodicity? That illumination from a bright moon may inhibit the migration is suggested by several European authors (PETERson, 1906; Lowe, 1952; Frost, 1950), and has been substantiated with experimental evidence in the present investigation. This leads to the expectation that the early evening activity would be pronounced on nights when the moon is down during those hours, and reduced in other phases of the lunar cycle. The relationship between migration and lunar period has been discussed by several authors (BoEtius, 1967; MEYER, 1938; Nolte, 1938; Frost, 1950; Knöpp, 1952; Lowe, 1952; Jens, 1953; Deelder, 1954; Winn \& HamMEN, 1969; WINN et al., 1975), all of whom generally agree to an increase in silver eel catches during the waning moon. If, as is suggested, the moon influences eel migration, it is important to note that this is probably a direct effect of its light rather than any other possible periodic effect. Low (1952) noted that in a heavy fog, or when the water was unusually turbid, eels ran even under a full moon. The present work has shown that, early in the third quarter, eels were active on clear nights, with nearly all of the experimental animals moving during two hours of darkness between sunset and the rising of a bright moon. Catch data from Jens (1953), SMIth \& Saunders (1955), WinN \& Hammen (1969), and Deelder (1970) have been plotted in two categories, those from nights with moonlight in the early evening, and those without. The majority of peak catches fell in the latter category.

Evidently the presence or absence of moonlight during the early evening accounts for the observed periodicity in silver eel activity and migration. DeELder (1970) speculated briefly upon this idea with regard to the European species; however, this paper reports the initial experimental data and several additional observations. The correlations explains the increased eel catches for $A$. rostrata beginning with the waning third quarter moon, when the moon rises later each night, providing longer periods of complete darkness, under whose cover the eels complete much, if not all, of their daily migration. Evenings are sufficiently dark until several days after the new moon (at which time the moon rises and sets with the sun). After the new moon, however, the moon sets later into the evening, providing illumination during the critical early evening hours and subsequently retarding the migration. Secondary effects of waterflow, turbidity, rainfall, fog, and cloud can be expected to modify the expression of the basic relationship between lunar period and migration. It will be necessary to determine, by experiment, whether a peak in activity follows the setting 
of a bright moon a few hours before dawn. This would establish whether the period of intense activity invariably occurs only in the evening hours.

Lunar influences other than the direct effect of light must not be ruled out. BoEtius (1967) has shown a lunar periodic rhythmicity in eel activity in the absence of light cues. In the experiments reported here, locomotion was artificially induced during daylight hours, indicating that the activity is under the essentially exogenous control of the environmental light cycle. This is in agreement with the work of BoHun \& WINN (1966) on the yellow eel stage. However, while $80 \%$ of the eels responded in the first hour when the tank was made dark $2^{1 / 2}$ hours before sunset, only $10 \%$ responded in the first hour when the tank was darkened 4 hours before sunset. This might suggest that the onset of locomotor activity can be shifted out of phase only to a certain point, indicating the presence of an endogenous factor as well. Additional evidence which might indicate the presence of an endogenous component can by seen by comparing the activity which followed a new moon with the activity following a full moon. The new moon activity was markedly less peaked and extended over 6 hours until $100 \%$ of the eels had moved, while activity in the third and early part of the fourth quarter was strongly peaked into a two hour period. In the first case, the moon sets with the sun, giving a moonless night; in the second case, an evening moonrise gives only several hours of darkness. Could it be that the behavior of the eel takes this into account?

\section{SUMMARY}

1. Behaviour of migratory silver eels and immature yellow eels, Anguilla rostrata, was studied in a choice-chamber apparatus.

2. Silver eels display a negative rheotaxis in both well water and natural stream water.

3. Silver eels reversed the sign of their response, to a positive rheotaxis, when salt water was introduced into the tank.

4. Rheotaxis and the salinity response are proposed as an effective orientation mechanism in the seaward migration of the silver eel. Responses are anticipatory in nature and are thought to be only part of a sequential arrangement of orientation behaviours.

5. Yellow eels showed no rheotactic response in August, but displayed a negative rheotaxis two months later into the fall. This seasonal difference in rheotactic responses of the yellow eels suggests periodic movement away from a home range in what might constitute a "dry run" for the eventual offshore migration.

6. Yellow and silver eels in heterogenous samples showed similar rheotactic responses in fresh water but were segregated by response in salt water.

7. The non-orientation of the yellow eels in the freshwater-saltwater choice suggests that it is the response to salinity which contains the yellow eel in its feeding habitat and later guides the silver eel away from it.

8. Perception of saltwater by silver eels is olfactory.

9. Locomotor activity of silver eels peaked to coincide with periods of naturally 
occurring darkness, between sunset and moonrise. The relationship between eel migration and lunar period is discussed in this respect.

10. Exogenous control over locomotor activity is indicated by experiments which induced activity during daylight hours. The presence of an endogenous factor is also suggested.

Acknowledgements. My thanks go to Drs. H. E. Winn, D. M. Pratt, W. H. KRueger, C. R. SHoop and H. P. Jeprries for their advice and review of the manuscript. My appreciation to Dr. R. C. Hanumara and D. Vaughan for their help with the statistics, and to J. StolGrTIs of the Division of Fish and Wildlife, Rhode Island Department of Natural Resources, for the loan of the state hatchery truck. Thanks also to D. JAROCa for preparing the figures and to J. Fischer for typing the manuscript. This work was largely supported by U.S. Public Health Service Grant No. 5 TO1E SS00104-06 from the Institute of Environmental Biology, and by an ONR grant awarded to Dr. H. E. WINN.

\section{LITERATURE CITED}

Baggerman, B., 1957. An experimental study on the timing of breeding and migration in the three-spined stickleback (Gasterosteus aculeatus L.). Archs néerl. Zool. 12, 105-318.

- 1960. Salinity preference, thyroid activity and the seaward migration of four species of Pacific salmon (Oncorhynchus). J. Fish. Res. Bd Can. 17, 295-322.

Bardach, J., FujIYA, M. \& Holl, A., 1967. Investigations of external chemoreceptors of fishes. In: Olfaction and taste. II. Ed. by T. HAyoshr. Pergamon Pr., Oxford, 647-665.

Bieder, R. C., 1971. Age and growth in the American eel, Anguilla rostrata (LeSueur), in R. I. M.S. Thesis., Univ. Rhode Island, $42 \mathrm{pp}$.

Bö̈Trus, J., 1967. Experimental indication of lunar activity in European silver eels, Anguilla anguilla (L.). Meddr Danm. Fisk.-og Havunders. 6, 1-6.

BohUn, S. \& WINN, H. E., 1966. Locomotor activity of the American eel (Anguilla rostrata). Chesapeake Sci. 7, 137-147.

BRÄUTIGAM, R., 1961. Über Versuche zur Intensivierung des Blankaalfanges durch die Kombination von Lichtsperren und Großreusen und ihre grundsätzlichen Bedingungen. Fisch.Forsch. 4, 19-25.

DeEzDER, C. L., 1954. Factors affecting the migration of the silver eel in Dutch inland waters. J. Cons. perm. int. Explor. Mer. 20, 177-185.

- 1970. Synopsis of biological data on the eel Anguilla anguilla (Linnaeus) 1758. F.A.O. Fish. Synopses 80.

Frost, W. E., 1950. The eel fisheries of the River Bann, Northern Ireland, and observations on the age of the silver eel. J. Cons. perm. int. Explor. Mer. 16, 358-383.

Gunning, G. E. \& Shoop, C. R., 1962. Restricted movements of the American eel, Anguilla rostrata (LESUEUR) in freshwater streams, with comments on growth rate. Tulane Stud. Zool. 9, 265-272.

Harden Jones, F. R., 1968. Fish Migration. Arnold, London, 325 pp.

Jens, G., 1953. Über den lunaren Rhythmus der Blankaalwanderung. Arch. FischWiss. 4, 94-110.

Knöpp, H., 1952. Die Laichwanderung des Aales (Anguilla vulgaris) und ihre Beziehungen zu Mondstand und Wetter. Zool. Anz. 149, 160-177.

Lowe, R. H, 1952. The influence of light and other factors on the seaward migration of the silver eel (Anguilla anguilla L.). J. Anim. Ecol. 21, 275-309.

MCINERNEY, J. E., 1964. Salinity preference: an orientation mechanism in salmon migration. J. Fish. Res. Bd Can. 21, 995-1018. 
ManN, H., 1964. Über das Rückkehrvermögen verpflanzter Fluß-Aale. Arch. FischWiss. 15, $177-185$.

MEDCof, J. C., 1969. Fishermen's reports of freshwater and saltwater migrations of Nova Scotia eels (Anguillat rostrata). Can. Fld. Nat. 83, 132-138.

Meyer, P. F., 1938. Die Beeinflussung des Blankaalfanges an der Rügenschen Küste durch meteorologische und kosmische Faktoren. Z. Fisch. 36, 634-637.

Mrtes, S. G., 1968. Laboratory experiments on the orientation of the adult American eel, Anguilla rostrata. J. Fish. Res. Bd Can. 25, 2143-2155.

NoLTE, W., 1938. Die Blankaalfischerei mit großen Reusen an den Küsten Rügens. Z. Fisch. 36, $681-725$.

OTto, R. G. \& MCINERney, J. E., 1970. Development of salinity preference in pre-smolt coho salmon. J. Fish. Res. Bd Can. 27, 793-800.

Peters, M., 1971. Sensory mechanisms of homing in salmonids: a comment. Behavior 39, 18-19.

Petersen, C. G. J., 1906. The influence of light on the migration of the eel. Rep. Dan. biol. Stn 14, 3-9.

SIEGEL, S., 1956. Nonparametric statistics. McGraw-Hill, New York, 312 pp.

Smith, M. W. \& Saunders, J. W., 1955. The American eel in certain fresh waters of the Maritime Provinces of Canada. J. Fish. Res. Bd Can. 12, 238-269.

T'EsCH, F. W., 1967. Homing of eels (Anguilla anguilla) in the southern North Sea. Mar. Biol. 1, 2-9.

- 1974. Influence of geomagnetism and salinity on the directional choice of eels. Helgoländer wiss. Meeresunters. 26, 382-395.

— \& Lelek, A., 1973. An evaluation of the directional choice in the eel, in captivity. Arch. FischWiss, 24, 237-251.

Vladykov, V. D., 1971. Homing of the American eel, Anguilla rostrata, as evidenced by returns of transplanted tagged eels in New Brunswick. Can. Fld Nat. 85, 241-248.

WALD, G., 1958. The significance of vertebrate metamorphosis. Science, N.Y. 128, 1481-1490.

Winn, H. E. \& Hammen, S., 1969. Migratory habits of the American eel pose problems for biologists. Maritimes 43, 3-5.

- Richkus, W. A. \& WINN, L. K., 1975. Sexual dimorphism and natural movements of the American eel (Anguilla rostrata) in Rhode Island streams and estuaries. Helgoländer wiss. Meeresunters. 27, 156-166.

Author's address: Dr. J. H. W. HaIN

Graduate School of Oceanography

University of Rhode Island

Kingston, Rhode Island 02881

USA 